\title{
NILAI-NILAI MULTIKULTURAL DALAM KEHIDUPAN SISWA
}

\author{
S. Chandra' ${ }^{1}$ I.W. Lasmawan ${ }^{2}$, I.N. Suastika ${ }^{3}$ \\ ${ }^{123}$ Program Studi Pendidikan IPS, Universitas Pendidikan Ganesha, Singaraja \\ e-mail: satriachandra249@gmail.com ${ }^{1}$, lasmawanizer@yahoo.com² ${ }^{2}$, inengahsuastika@gmail.com ${ }^{3}$
}

\begin{abstract}
Abstrak
Kajian ini hendak mencoba menelaah secara kritis praktek-praktek nilai-nilai multikultural yang umumnya kurang memperhatikan aspek akulturasi budaya yang menyertainya dan juga mencari alternatif solusi pemecahannya demi mendukung tercapainya pendidikan yang berbasis character building di negara ini. Pada kenyataannya, praktek nilai-nilai multikultural senantiasa menyediakan ruang adanya insersi nilai-nilai budaya asing masyarakat penuturnya yang belum tentu sejalan dengan nilai-nilai budaya masyarakat kita. Sejalan dengan tujuan pendidikan nasional, nampaknya salah satu upaya yang bisa dilakukan untuk mengantisipasi dampak insersi budaya asing tersebut adalah dengan mengintegrasikan nilai-nilai budaya lokal Indonesia pada nilai-nilai multikultural sebagai alternatif cara guna mendukung upaya pemerintah dalam menggalakkan pendidikan berbasis karakter yang diyakini sangat penting untuk menumbuhkan, meningkatkan dan memelihara semangat nasionalisme generasi penerus bangsa.
\end{abstract}

Kata kunci: Budaya Lokal; Nilai-Nilai Multikultural, Pembelajaran; Pendidikan Karakter

\begin{abstract}
This study intends to examine critically the practices of multicultural values which generally do not pay attention to the cultural acculturation aspects that accompany them and also seek alternative solutions to solve them in order to support the achievement of character building based education in this country. In fact, the practice of multicultural values always provides a space for the insertion of foreign cultural values of the speakers' communities which is not necessarily in line with the cultural values of our society. In line with the objectives of national education, it seems that one of the efforts that can be made to anticipate the impact of the insertion of foreign culture is to integrate Indonesian local cultural values into multicultural values as an alternative way to support government efforts in promoting character-based education which is believed to be very important to foster, enhance and maintain the spirit of nationalism of the nation's next generation.
\end{abstract}

Keywords: Local Culture, Multicultural Values; Learning; Character Education

\section{PENDAHULUAN}

Secara umum diyakini bahwa pendidikan memainkan peran paling penting dalam pembangunan suatu bangsa. Pendidikan dapat dianggap sebagai investasi dalam pembentukan manusia yang menjadi fondasi bagi pertumbuhan ekonomi dan perkembangan masa depan suatu negara. Pendidikan merupakan sebagai proses pembelajaran yang simultan dan terus menerus sepanjang hayat. Baik pendidikan yang terjadi dalam keluarga, diselenggarakan oleh sekolah, maupun dalam lingkungan masyarakat luas ( Ekha Budi dalam Sutarjo Adisusilo: 2016, 4). Pemerintah kita bahkan telah memberi secara eksplisit definisi istilah pendidikan dalam Undang-Undang Republik Indonesia tentang Sistem Pendidikan Nasional yang dapat dianggap sebagai: ... upaya yang sadar dan terencana dalam menciptakan lingkungan belajar dan proses belajar sehingga peserta didik akan menjadi mampu mengembangkan potensi penuh mereka untuk memperoleh kekuatan spiritual dan agama, mengembangkan kontrol diri, kepribadian, kecerdasan akhlak dan akhlak mulia dan keterampilan yang dibutuhkan seseorang untuk dirinya sendiri, untuk masyarakat, untuk bangsa, dan untuk Negara. Pendidikan nasional berarti pendidikan berdasarkan Pancasila dan UUD 1945, dan berakar pada nilai-nilai agama, budaya nasional Indonesia, dan budaya yang sesuai dengan kebutuhan zaman yang senantiasa berubah. (Undang-Undang Republik Indonesia tentang Sistem Pendidikan Nasional (Bab 1 Pasal 1 dan 2). 
Multikulturalisme secara sederhana dapat dikatakan pengakuan atas pluralisme budaya. Pluralisme budaya bukanlah suatu yang "given" tetapi merupakan suatu proses internalisasi nilai-nilai di dalam suatu komunitas. Tidak mengherankan apabila tokoh politik demokrasi dan pendidikan demokrasi, John Dewey, telah melahirkan karya besarnya mengenai hubungan antara demokrasi dan pendidikan (Ratih dalam Tilaar, 2017: 15). Kebudayaan telah mengalami proses perkembangan secara bertahap dan berkesinambungan seperti yang dikenal sebagai evolusi kebudayaan. Evolusi kebudayaan ini berlangsung sesuai dengan perkembangan budi daya atau akal pikiran manusia dalam menghadapi tantangan hidup dari waktu ke waktu. Proses evolusi untuk tiap kelompok masyarakat diberbagai tempat berbeda-beda, tergantung pada tantangan, lingkungan, dan kemampuan intelektual ( Ridwan, 2015:261 ).

Keberagaman masyarakat memiliki ciri khas yang suatu saat bisa berpotensi negatif bagi kehidupan bangsa tersebut. Van de Berghe sebagaimana dikutip oleh Elly M. Setiadi menjelaskan bahwa masyarakat majemuk atau masyarakat yang beragam selalu memiliki sifat-sifat dasar sebagai berikut:

1. Terjadinya segmentasi ke dalam kelompok-kelompok yang seringkali memiliki kebudayaan yang berbeda.

2. Memiliki struktur sosial yang terbagi-bagi ke dalam lembaga-lembaga yang bersifat nonkomplementer.

3. Kurang mengembangkan konsensus diantara para anggota masyarakat tentang nilai-nilai sosial yang bersifat mendasar.

4. Secara relatif, sering kali terjadi konflik diantara kelompok yang satu dengan yang lainnya.

5. Secara relatif, integrasi sosial tumbuh di atas paksaan dan saling ketergantungan di dalam bidang ekonomi.

6. Adanya dominasi politik oleh suatu kelompok terhadap kelompok yang lain ( Ratih dalam Elly M. Setiadi, dkk, 2017:39).

Dari beberapa definisi di atas penulis menyimpulkan bahwa toleransi adalah suatu sikap atau sifat dari seseorang untuk membiarkan kebebasan kepada orang lain serta memberikan kebenaran atas perbedaan tersebut sebagai pengakuan hak-hak asasi manusia. Toleransi merupakan sikap yang sudah menghiasi setiap hati manusia tanpa terkecuali, sehingga memudahkan orang untuk saling menghormati dan menghargai segala bentuk perbedaan dengan sikap toleransi tersebut, karena manusia mengedepankan aspek persaudaraan yang berdasarkan kemanusiaan. Jadi secara umum toleransi merupakan penghargaan dan penghormatan terhadap kebhinekaan (pluralitas) yang mengedepankan aspek kemanusiaan (humanisme) dan etika sebagai pilar utama penyangga terbentuknya masyarakat yang terbuka dan mampu bekerja sama dalam kemajemukan. Agar tujuan itu tercapai perlu adanya metode pembelajaran dalam pendidikan di sekolah, Metode pembelajaran merupakan bagian terpenting dalam melaksanakan proses belajar. Pembelajaran sebaiknya dilaksanakan dengan cara menarik yang mampu membangkitkan minat siswa untuk melaksanakan pembelajaran. Hamzah dalam Nurdin (2018: 7), mendefinisikan metode pembelajaran sebagai cara yang digunakan guru dalam menjalankan fungsinya dan merupakan alat untuk mencapai tujuan pembelajaran. Studi khusus ini, mencoba untuk melihat lebih dekat pada praktik umum nilai-nilai multikultural di SMK PGRI 1 Badung, karena fakta bahwa pendidikan dianggap memiliki peluang terbesar untuk menyediakan peserta didik untuk melakukan kontak langsung dengan masyarakat dan budaya. Sejalan dengan tujuan pendidikan nasional, studi khusus ini juga cenderung mengusulkan perspektif baru dalam praktik nilai-nilai multikultural dengan memasukkan budaya untuk mempromosikan pendidikan karakter di Indonesia.

Tujuan penelitian ini adalah untuk:

1. Mendeskripsikan perencanaan nilai-nilai multikultural di SMK PGRI 1 Badung.

2. Mendeskripsikan pelaksanaan nilai-nilai multikultural di SMK PGRI 1 Badung.

3. Mendeskripsikan hasil pelaksanaan nilai-nilai multikultural di SMK PGRI 1 Badung. 
4. Mendeskripsikan faktor-faktor apa saja yang mendukung dan menghambat pelaksanaan nilai-nilai multikultural di SMK PGRI 1 Badung.

Dari fenomena yang terjadi maka penulis tertarik untuk meneliti bagaimana pengaruh nilai-nilai multikultural terhadap pengembangan sikap siswa dalam rangka membangun toleransi kebhinnekaan dalam sekolah dengan mengambil judul "Nilai-Nilai Multikultural Dalam Kehidupan Siswa Di SMK PGRI 1.

\section{METODE}

SMK PGRI 1 Badung didirikan pada tahun 1990 yang mengusung konsep Sekolah Modern, Konsep ini bertujuan untuk membentuk citra sekolah yang dapat mengikuti arus zaman dibidang pembelajarannya, SK Pendirian sekolah tertuang dalam nomor 85/K.II.13/A.1/1990 dengan tanggal pendirian SK pada tanggal 25 Juni 1990, sekolah SMK PGRI 1 Badung beroperasional secara penuh pada tanggal 2 April 1991 dengan SK izin operasional 186/I19/LI/I.1991, SMK PGRI 1 Badung sepenuhnya di kelola oleh yayasan dengan NPSN 50101606. SMK PGRI 1 Badung beralamat di Jl. Leko Latu Gerih No.84, Kelurahan Abiansemal, Kecamatan Abiansemal, Kabupaten Badung, Provinsi Bali, 80352 dengan posisi geografis -8.546022 lintang dan 115.213493 bujur. Dengan batas-batas sekolah Selatan berbatasan dengan rumah pak Gede, Utara berbatasan dengan sawah penduduk, Timur berbatasan dengan sawah penduduk, dan barat berbatasan dengan jalan raya gerih, SMK PGRI 1 Badung terletak di Desa Gerih. Penelitian ini dilaksanakan oleh peneliti pada semester genap tahun pelajaran 2019/2020. Diawali dengan observasi pada bulan Maret 2020 dan dilanjutkan dengan melakukan penelitian pada bulan Mei 2020 . Penelitian ini berbentuk penelitian kualitatif dengan studi naturalistik dan eksploratif. Menurut Alwasilah dalam Arikunto (2015:131),sampel didefinisikan sebagai pemilihan sejumlah subjek penelitian sebagai wakil dari populasi yang diteliti. Jadi dapat disimpulkan, sampel adalah contoh yang diambil dari sebagian populasi penelitian yang dapat mewakili populasi. Sesuai dengan desain penelitian yang digunakan dalam penelitian ini, yaitu penelitian ini menggunakan metode kualitatif atau naturalistik karena dilakukan pada kondisi alamiah. Strategi penelitian kualitatif yang digunakan dalam penelitian ini adalah studi naturalistik dan eskploratif. Menurut M. Arifin dalam Yusuf (2016: 144) populasi merupakan keseluruhan atribut dapat berupa manusia, objek, atau kejadian yang menjadi fokus penelitian. Populasi adalah seluruh data yang menjadi perhatian peneliti dalam suatu ruang lingkup dan waktu yang ditentukan. Sampel adalah sebagian dari jumlah dan karakteristik yang dimiliki oleh populasi M. Arifin dalam Sugiyono ( 2016: 81). Sumber data yang digunakan dalam penelitian ini adalah informan atau narasumber, tempat dan permasalahan serta arsip dan dokumen Ekha Bhudi Santosa, dkk dalam Sutopo (2018, 5 ). Ekha Bhudi Santosa, dkk dalam Sugiyono (2018: 5) menyatakan lima macam teknik pengumpulan data yaitu observasi, wawancara, kuesioner, dokumen dan gabungan keempatnya. Pengumpulan data pada penelitian ini dilakukan melalui metode observasi, wawancara dan mencatat dokumen. Model analisis yang digunakan dalam penelitian ini adalah model analisis interaktif. Penelitian kualitatif di dalamnya terdapat beberapa cara untuk mengembangkan validitas data penelitian, antara lain teknik trianggulasi dan review informan. Model analisis interaktif terdiri dari pengumpulan data, reduksi data, sajian data dan pengamabilan kesimpulan atau verifikasi data. Penjelasan secara rinci langkah-langkah penelitian dari awal hingga akhir. Langkah-langkah tersebut meliputi: (1) persiapan; (2) pelaksanaan; (3) tahap analisis dan pengolahan data; dan (4) Penyajian Simpulan/Hasil.

\section{HASIL DAN PEMBAHASAN}

\section{Hasil}

Setelah dilakukan pengumpulan data dan analisa data maka dapat diketahui hasil penelitian ini sebagai berikut :

1. Potret Nilai-nilai Multikultural SMK PGRI 1 Badung.

a. Pengenalan Keberagaman

Pengenalan keberagaman yang dilakukan di SMK PGRI 1 Badung diawali dengan 
mengenalkan keberagaman siswa yang ada disekitar baik itu lingkungan sekolah maupun lingskungan masyarakat sekitar. Perbedaan jenis kelamin, bahasa, agama, dan suku bangsa termasuk perbedaan sosial merupakan hal yang mutlak didalam Negara Kesatuan Republik Indonesia. Penanaman nilai-nilai multikultural yang dapat disebut dengan pendidikan multikultural, tidak menjadi satu mata pelajaran khusus namun diintegrasikan kedalam pembelajaran dan kegiatan sehari-hari. Pendidikan multikultural tidak hanya di fokuskan dalam mata pelajaran IPS. Disamping itu, pengenalan keberagaman oleh pendidik dilakukan dengan menciptakan aturan kelas salah satu dengan tolong menolong sesama tanpa membedakan. Tetapi tidak terlepas juga dari peran pendidik dalam mengembangkan nilai-nilai karakter yang ada terhadap peserta didik di SMK PGRI 1 Badung. Pendidik berupaya menciptakan kultur kelas yang baik sehingga para siswa dapat menerima satu sama dengan yang lain. Selain pengenalan keberagaman tentu saja tidak terlepas dari metode pembelajaran pembelajaran yang sudah dipraktekkan dalam kelas X TB 2, metode pembelajaran inkuiri yang lebih terpusat kepada siswa merupakan metode yang menurut peneliti layak untuk digunakan, tetapi dalam hal ini peneliti tetap berpedoman dari hasil para informan.

\section{Penanaman Multikultural}

Penanaman nilai-nilai multikultural yang dilakukan di SMK PGRI 1 Badung dengan mewujudkan pembentukan karakter siswa melalui nilai-nilai keutamaan yang ditanamkan diantaranya yaitu nilai toleransi, nilai demokrasi, mendahulukan dialog ( aktif ), cinta tanah air, nilai inklusif, nilai tolong menolong, nilai kemanusiaan, dan berbaik sangka. Penanaman nilai-nilai multikultural dilakukan setiap hari baik dalam masa pembelajaran atau diluar pembelajaran dan diterapkan kepada seluruh siswa yang berbeda latar belakang sosial maupun budaya, namun pada penyampaiannya guru juga harus membimbing dalam penerapan nilai-nilai multikultural. Hal ini disebabkan beberapa siswa ada yang memiliki perbedaan latar belakang sosial dan budaya nya sehingga perlu adanya bimbingan dari guru agar tidak terjadi diskriminasi didalam lingkungan sekolah. Dalam kegiatan sehari-hari guru juga memperingatkan kepada seluruh siswa agar saling menghormati dan menghargai perbedaan dengan pengucapan bahasa yang baik dan sederhana dapat di mengerti oleh seluruh siswa, penggunaan bahasa yang mudah dan sederhana dapat dicerna oleh siswa juga perlu di perhatikan agar tidak terjadi nya kesimpang siuran dalam penyampaiannya dan para siswa bisa mengerti akan ucapan dari para guru, percakapan sehari-hari juga para siswa di anjurkan menggunakan bahasa indonesia yang baik dan benar untuk memudahkan komunikasi antar siswa yang sama-sama memiliki perbedaan latar belakang sosial dan budaya. Penanaman nilai-nilai multikultural pada kelas X TB 2 SMK PGRI 1 Badung yang dikemukakan oleh bu Kadek dan bu Susi diterapkan langsung dalam proses pembelajaran didalam kelas. Disamping menggunakan contoh langsung dalam penanaman nilai-nilai keberagaman, guru menggunakan komunikasi dua arah yang melibatkan siswa didalamnya baik pada saat pembelajaran berlangsung maupun pembahasan masalah tertentu. Penanaman nilai-nilai keberagaman yang dilakukan dilingkungan SMK PGRI 1 Badung baik saat pembelajaran serta contoh sikap toleransi yang ditunjukkan guru atau warga sekolah yang ada, pada berjalannya waktu telah memberikan hasil nyata yaitu sikap siswa terhadap sesama. Beberapa siswa telah mampu bertoleransi dan menerima teman-teman mereka yang berbeda baik secara sosial maupun budaya, bahkan pada teman-teman mereka yang memiliki perbedaan latar ekonomi.

3. Media Pendukung Penanaman Nilai-nilai Multikultural

Penanaman nilai-nilai multikultural tidak terlepas dari sarana dan prasarana pendukung dan penyampaiannya yang terlibat langsung dalam toleransi. Penggunaan media pembelajaran yang beragamam akan membuat siswa lebih membuat siswa lebih tertarik dan mudah dalam memahami maksud yang disampaikan oleh guru. SMK PGRI 1 Badung dalam hal ini telah menggunakan media pembelajaran yang beragam pada pendidikan multikultural uang disampaikan. Misalnya saja pada buku-buku bacaan yang tersedia di perpustakaan sekolah maupun pojok baca di setiap kelas yang terutama kelas X TB 2 telah memuat nilainilai multikultural serta slogan atau poster-poster yang bertemakan multikultural, beberapa 
dapat ditemukan didinding-dinding sekolah, gerbang masuk sekolah, kantin, dan ruang kantor guru, disamping buku-buku bacaan sekolah juga telah menyediakan satu tempat persembahyangan bagi khusus umat Hindu untuk para siswa dan guru yang pemeluk agama Hindu, itu merupakan termasuk media pendukung yang berkaitan dengan sosialiasi penanaman nilai-nilai multikultural.

Pendidikan multikultural yang dilakukan di SMK PGRI 1 Badung tidak terpaku pada media pembelajaran tertentu, guru dapat berkreasi dan berinovasi dalam penggunaan media pembelajaran pendidikan multikultural yang menarik bagi siswa. Setiap guru dimungkinkan dapat menggunakan media pembelajaran yang berbeda-beda. Pada beberapa kesempatan para guru juga dapat membuat media pembelajaran pendidikan yang melibatkan siswa didalamnya.

4. Faktor pendukung dan penghambat sosialisasi nilai-nilai multikultural di SMK PGRI 1 Badung.

Penanaman nilai-nilai multikultural SMK PGRI 1 Badung dalam penerapannya tidak selalu berjalan dengan lancar, terdapat beberapa faktor pendukung dan penghambat didalamnya.

a. Faktor Pendukung

SMK PGRI 1 Badung sebagai agen sosialisasi nilai-nilai multikultural bagi siswa nya merupakan agen kedua setelah para siswa mendapatkan sosialisasi primer dilingkungan rumah mereka. Penanaman nilai-nilai multikultural yang berlangsung didalam maupun diluar kelas dapat berjalan dengan baik tentunya tidak terlepas dari peran sekolah, guru, dan siswa yang terlibat langsung didalamnya. Sekolah sebagai lembaga pendidikan dalam hal ini telah menciptakan kultur sekolah yang memperkenalkan keberagaman disekitar lingkungan mereka sedini mungkin. Penciptaan kultur sekolah yang mendukung penanaman nilai-nilai multikultural di SMK PGRI 1 Badung, terlihat salah satunya pada siswa siswi yang tidak hanya berasal dari satu daerah tetapi ada yang berasal dari daerah lain. Dari segi perbedaan latar belakang sosial dan agama masing-masing siswa juga merupakan contoh nyata lingkungan yang beragam, hal tersebut tentunya mendukung penanaman nilai-nilai multikultural pada siswa. Lingkungan yang beragam membuat siswa mudah memahami apa yang dimaksud dengan keberagaman disekitar mereka. Salah satu bentuk toleransi keberagaman yaitu adanya tempat ibadah untuk agama Hindu yang disebut Padma ( julukan tempat ibadah khusus agama Hindu ), setiap hari para siswa yang memeluk agama Hindu dapat menunaikan sembahyang nya di Padma yang sudah disediakan di sekolah pada setiap hari.

Pada setiap ruang kelas terdapat pojok keberagaman yang diisi oleh hasil karya dan kreativitas siswa. Desain kelas tersebut merupakan kebijakan yang diambil oleh sekolah dalam upaya pengenalan keberagaman bagi para siswa. Perayaan dan pengenalan hari besar keagamaan yang diadakan pihak sekolah merupakan penciptaan kultur sekolah yang mengajarkan dan memperkenalkan keberagaman dalam hal agama. Dalam hal ini, kebijakan sekolah merupakan faktor pendukung utama dalam pendidikan multikultural di SMK PGRI 1 Badung.

b. Faktor Penghambat.

Pelaksanaan sosialisasi nilai-nilai multikultural yang berlangsung di SMK PGRI 1 Badung, tidak lepas dari hambatan dalam perjalanannya. Pihak sekolah yang telah menerapkan filosofi mengenai landasan SMK PGRI 1 Badung didirikan yaitu sekolah multikultural dimana sekolah menerima siswa siswi dari berbagai latar belakang budaya dan sosial dengan penciptaan kultur sekolah yang positif, merupakan faktor pendukung dalam sosialisasi nilai-nilai multikultural yang dilakukan. Disamping faktor pendukung tersebut, terdapat faktor penghambat dalam proses penanaman nilai-nilai multikultural yang ada, baik berasal dari pihak sekolah dan siswa maupun pihak keluarga siswa.

1) Faktor Penghambat Internal

Hambatan yang muncul ketika guru melakukan sosialisasi nilai-nilai multikultural, siswa terkadang belum sepenuhnya memahami apa yang 
disampaikan oleh guru berkenaan dengan nilai-nilai keberagaman yang ada sehingga beberapa anak terkadang belum mengerti keadaan teman-teman yang berbeda baik secara sosial maupun kemampuan dalam belajar. Ketidak pahaman siswa mengenai perbedaan latar belakang yang berbeda disebabkan karena beberapa dari mereka belum memahami bagaimana sikap toleransi yang seharusnya yang dilakukan dalam pergaulan sehari-hari. Selain itu, para siswa lebih kritis dalam menanggapi sesuatu sehingga guru harus menggunakan bahasa yang mudah dipahami oleh siswa. Misalnya dalam pemilihan kata atau penggunaan bahasa, guru lebih memperhatikan kalimat yang akan diucapkan karena ketika muncul kalimat asing dan belum mengetahui artinya, mereka akan bertanya serta meminta penjelasannya. Pihak sekolah telah menyediakan buku bertemakan multikultur, baik diperpustakaan maupun dipojok baca setiap kelas. Namun pembekalan atau agenda khusus yang diberikan pihak sekolah kepada guru berkaitan dengan sosialisasi nilai-nilai keberagaman belum maksimal dilakukan. Penyisipan pendidikan multikultural pada pembelajaran yang berlangsung, belum dibarengi dengan agenda khusus mengenai strategi pembelajaran dikalangan guru SMK PGRI 1 Badung.

2) Faktor Penghambat Eksternal

Hambatan lain yang dihadapi pihak sekolah yaitu pola pendidikan yang didapatkan anak di rumah. Terkadang pendidikan yang didapat anak di rumah tidak sejalan dengan penanaman nilai-nilai multikultural di sekolah. Disaat hari besar Galungan dan Kuningan bagi umat Hindu juga seperti itu para siswa juga ikut serta berpartisipasi tanpa ada memandang latar belakang budaya lainnya, tidak hanya umat Hindu tetapi umat lainnya bisa merayakan bersama-sama di Sekolah Hal tersebut membuat beberapa orang tua siswa berpikir untuk apa mengenal atau memeriahkan perayaan agama lain.

5. Implementasi Nilai-nilai Multikultural di SMK PGRI 1 Badung.

Toleransi merupakan sikap yang perlu ditanamkan dalam kondisi bangsa yang multikultural. Toleransi menjadi salah satu wujud upaya untuk menjaga ketentraman dalam setiap perbedaan yang terjadi pada segmentasi masyarakat. Adanya sikap ini mampu memperkecil gesekan-gesekan yang memicu perpecahan dan persengketaan. Khususnya dalam masalah agama, toleransi menjadi sikap yang penting ditanamkan kepada seluruh warga negara, khususnya generasi muda. Urgensi ini menjadikan pendidikan formal sangat bertanggung jawab dalam melakukan penanaman dan pembiasaan kepada anak untuk mampu bertoleransi yang diwujudkan dengan saling menghormati dan menghargai perbedaan agama yang dianut. Sekolah mengambil peran strategis dalam melakukan pembinaan karakter, khususnya karakter toleransi. Dengan pendidikan yang diselenggarakan dalam pembelajaran intruksional, ekstrakurikuler dan juga berbagai pembiasaan menjadi cikal bakal sikap toleransi generasi muda untuk dimanifestasikan ke dalam berbagai wujud perilaku. Ditengah semakin menguatnya isu-isu yang erat dengan potensi disintergasi bangsa, maka toleransi di sekolah adalah salah satu solusi agar setiap generasi muda tidak mudah termakan oleh isu-isu perpecahan dan selalu berusaha untuk menjadi warga negara yang baik dalam menjalankan kehidupan bersama dengan ikatan satu bangsa dan satu negara. Pendidikan berkarakter dari sudut pandang sebagai siswa, merupakan bentuk pembiasaan yang diterapkan di sekolah. Pendidikan berkarakter adalah ciri khas pendidikan di SMK PGRI 1 Badung yang menuntut seluruh siswa agar mampu berperilaku toleransi. Seiring dengan pendapat tersebut bahwa penanaman nilai-nilai penting dalam pelaksanaan pendidikan karakter harus dimulai dari sekolah yang terintegrasi dengan keluarga dan masyarakat. Pendidikan berkarakter di SMK PGRI 1 Badung menjadi bermakna karena melibatkan sekolah, keluarga dan masyarakat untuk implementasi karakter. Namun peran sekolah menjadi sangat penting jika sekolah mejadi benteng pertahanan terakhir ketika orang tua mengabaikan dan tidak mempunyai kompetensi untuk mendidik. Melalui program yang terstuktur, penguatan karakter dimulai dari religiusitasnya. Religiusitasnya ini dimulai 
dari bagaimana siswa tumbuh menjadi muslim yang baik, penganut Nasroni yang baik, penganut katolik yang baik, dan penganut hindu yang baik. Dengan itu, sekolah memfasilitasi sarana ibadah serta guru-gurunya.

\section{Pembahasan}

SMK PGRI 1 Badung merupakan sekolah modern dan berbudaya, di mana pihak sekolah memperhatikan kemampuan semua anak didik dan berusaha memfasilitasi siswa dengan kebutuhannya. SMK PGRI 1 Badung yang terletak di lingkungan pedesaan terdiri dari siswa yang beragam baik sosial maupun budaya. Siswa berasal dari berbagai daerah, bukan hanya dari Bali. Di samping itu, siswa juga berasal dari latar belakang agama yang ada seperti Islam, Kristen, Katholik, dan Hindu.

SMK PGRI 1 Badung dalam hal ini sebagai agen sosialisasi sekunder, melakukan penanaman nilai-nilai multikultural pada pembelajaran sehari-hari sebagai wujud pendidikan multikultural kepada siswa. Pendidikan multikultural ini telah diterapkan sejak berdirinya SMK PGRI 1 Badung. Pada pelaksanaannya, pendidikan multikultural tidak dipisahkan menjadi mata pelajaran tersendiri namun disisipkan ke dalam mata pelajaran yang ada. Pendidikan multikultural yang berlangsung di dalam kelas diintegrasikan dengan mata pelajaran yang berkaitan dengan nilai-nilai multikultural, tidak menutup kemungkinan juga pada mata pelajaran lainnya.

Pendidikan multikultural dilakukan melalui beberapa metode bukan hanya disisipkan ke dalam pembelajaran yang berlangsung di dalam kelas, namun dilanjutkan dengan kegiatan di luar kelas seperti ekstrakulikuler, maupun kegiatan yang digelar oleh pihak sekolah. Selain itu, penanaman nilai-nilai multikultural dilakukan pada saat morning dan day carpet. Morning carpet dan day carpet biasanya digunakan oleh guru untuk mempersiapkan pelajaran atau mengevaluasi pembelajaran yang telah berlangsung namun pada kesempatan tersebut guru tidak jarang membahas masalah yang dihadapi oleh siswa dengan menyampaikan pesan di dalamnya yang dapat pula berisi penanaman nilai-nilai multikultural.

Lingkungan sekolah yang sedemikian rupa tercipta dan terkondisikan di SMK PGRI 1 Badung telah mendukung sosialisasi nilai-nilai keberagaman pada siswa. Keberagaman yang berada di sekitar mereka khususnya di lingkungan sekolah, membuat siswa dengan baik mengerti mengenai gambaran nyata keberagaman itu sendiri. Hal ini sejalan dengan pendapat yang dikemukakan oleh M. Ainul Yaqin mengenai pendidikan multikultural, yaitu merupakan strategi pendidikan yang diaplikasikan pada semua jenis mata pelajaran dengan cara menggunakan perbedaan-perbedaan kultural yang ada pada para siswa seperti perbedaan etnis, agama, bahasa, gender, kelas sosial, ras, kemampuan, dan umur agar proses belajar menjadi efektif dan mudah (2005: 25).

Pendidikan multikultural di SMK PGRI 1 Badung dilakukan juga melalui kebijakan yang diterapkan oleh pihak sekolah. Salah satunya dengan mengadakan kegiatan sekolah yang berkaitan dengan kebudayaan atau hari besar keagamaan yang ada. Kegiatan yang berkaitan dengan pengenalan kebudayaan, pihak sekolah pada tahun 2020 mengadakan perayaan Hari Raya Galungan dan Kuningan bagi umat HIndu. Sekolah menghias lingkungan sekolah dengan pernak-pernik khas perayaan Hari Raya Galungan dan Kuningan tersebut.

Penanaman nilai-nilai multikultural yang telah diterapkan pihak SMK PGRI 1 Badung meliputi nilai inklusif dengan penciptaan lingkungan sekolah yang beragam dari latar belakang siswa, baik sosial, budaya maupun kemampuan individu. Keberagaman yang ada di sekitar lingkungan sekolah membuat siswa mengenal dan belajar menerima satu sama lain. Keberagaman tersebut juga menumbuhkan sikap toleransi yang harus dijaga agar lingkungan tetap kondusif. Mereka telah dibiasakan dengan keadaan tersebut dan ditanamkan bagaimana bertoleransi kepada sesama begitupun dengan teman-teman mereka yang berkebutuhan khusus. Pada tahap ini, pihak sekolah telah menanamkan nilai toleransi. Nilai toleransi tersebut juga dibarengi dengan pengenalan keberagaman yang ada serta pengarahan dan contoh nyata dari guru maupun warga sekolah dalam menjalankan toleransi antar sesama. 
Pengkondisian lingkungan sekolah yang terdiri dari beragam latar belakang siswa dan pemodelan toleransi oleh edukator serta warga sekolah lainnya, sejalan dengan pendapat H.A.R Tilaar (2003: 182). Dengan demikian, pendidikan multikultural lebih tepat disebut sebagai suatu proses mata pelajaran. Atau dengan kata lain, di dalam lingkungan sekolah (school education) pendidikan multikultural merupakan pengembangan budaya pluralisme dalam kehidupan sekolah (school culture) sebagai lembaga masyarakat (social institution).

Penanaman nilai demokrasi juga telah dilaksanakan guru dengan banyaknya kesempatan yang diberikan dan diciptakan oleh pihak sekolah maupun guru kepada siswa dalam mengemukakan pendapat. Kesempatan tersebut membuat mereka secara perlahan belajar mengenai nilai demokrasi begitupun dengan sikap terbuka terhadap kritik ataupun saran yang disampaikan orang lain. Kebiasaan tersebut dijalankan baik di dalam kelas ketika pembelajaran berlangsung maupun di lingkungan sekolah, misalnya pada saat evaluasi sebelum menutup pelajaran, para siswa akan berdiskusi dengan dibimbing oleh guru, para siswa bebas memberikan pernyataan, Keadaan tersebut merangsang siswa belajar berdialog ketika masalah muncul diantara mereka serta melatih keberanian siswa dalam menyampaikan pendapat.

Pihak sekolah selain itu, menanamkan cinta tanah air pada siswa dengan mengenalkan kebudayaan Indonesia pada umum. Diskusi mengenai kebudayaan yang ada di Indonesia juga kerap dilakukan di dalam pembelajaran yang berkaitan dengan tema tersebut. Guru mengangkat suatu kebudayaan yang ada dengan disertai penggambaran secara nyata, seperti gambar maupun video, kemudian Guru mengajak siswa untuk berdiskusi mengenai kebudayaan tersebut atau sekedar bertanya. Pengenalan pahlawanpahlawan Indonesia juga dilakukan dalam berbagai kesempatan baik di dalam kelas maupun kegiatan sekolah.

Pendidikan multikultural yang dilakukan di SMK PGRI 1 Badung pada pemaparannya sesuai dengan teori interaksionisme simbolis yang di dalamnya terdapat interaksi sosial guna menyampaikan maksud dan tujuan yang diinginkan secara spesifik, salah satunya melalui sosialisasi. Siswa menerima sosialisasi nilai-nilai multikultural yang dilakukan oleh pihak sekolah maupun guru melalui interaksi sosial yang terjadi di lingkungan sekolah. Di mana bahasa merupakan unsur terpenting dalam interaksionisme simbolik. Bahasa yang digunakan oleh guru dalam sosialisasi nilai-nilai keberagaman kepada siswa diberikan secara sederhana sehingga mudah dimengerti oleh siswa dan memuat simbol-simbol dalam upaya penyampaian nilai-nilai multikultural yang ada. Simbol-simbol yang memuat nilai keberagaman terjabarkan salah satunya dengan atribut sekolah seperti majalah dinding, poster, buku, maupun karya siswa yang mencerminkan keberagaman diantara. Para guru dan sekolah berupaya menempatkan simbol-simbol tersebut di dalam maupun di luar kelas sebagai tempat bermain siswa sehingga siswa dapat dengan mudah membaca.

Para guru melakukan sosialisasi melalui beberapa cara dengan melibatkan siswa di dalamnya, sosialisasi nilai-nilai multikultural tidak menempatkan siswa hanya sebagai objek, namun mengajak siswa untuk mengembangkan apa yang mereka dapatkan. Pengembangan tersebut dirangsang melalui adanya kesempatan siswa untuk mengemukakan pendapatnya dan berdiskusi. Hal tersebut tercermin dalam kegiatan pendidikan multikultural yang melibatkan partisipasi siswa seperti diskusi bersama ketika membahas persoalan bersama baik di dalam maupun di luar kelas. Siswa mempunyai hak untuk memberikan pendapatnya namun tetap menghargai pendapat orang lain. Guru memberikan kesempatan yang seluasluasnya kepada siswa untuk ikut serta dalam penanaman nilai-nilai multikultural yang ada dan terlibat aktif di dalamnya dengan diadakannya berbagai kegiatan yang mengharuskan siswa mencari makna kemudian menentukan sikap yang seharusnya mereka lakukan, tentunya dengan pengawasan dari para gru. Misalnya pada kegiatan perayaan hari besar keagamaan atau kebudayaan yang dijadikan agenda sekolah dan melibatkan seluruh siswa dari berbagai macam latar belakang budaya dan sosial, pihak sekolah dalam hal ini berupaya memberikan makna mengenai keberagaman yang ada di sekitar mereka tidak menjadi masalah selama mereka dapat bertoleransi dan menghormati sesama. Siswa secara berkelanjutan ditanamkan mengenai keberagaman yang ada sehingga lambat laun 
dapat menentukkan sikap secara bijak atas perbedaan yang ada di sekitar lingkungan mereka.

\section{SIMPULAN DAN SARAN}

Nilai-nilai multikultural merupakan kekhasan dari SMK PGRI 1 Badung sebagai sekolah yang berketuhanan dan berkebudayaan yang berbeda-beda tetapi tetap menjaga toleransi keberagamannya, penerapan ini menghasilkan kebijakan yang mengutamakan pendidikan untuk menanamkan nilai-nilai karakter untuk membentuk generasi anak bangsa yang cerdas, trampil, cinta tanah air dan rukun akan sesama, berwawasan luas, dan berbudi pekerti luhur. Nilai-nilai multikultural dilaksanakan sebagai strategi pengembangan karakter secara makro yang dibuat oleh pihak sekolah yang selanjutnya diterjemahkan kedalam strategi pengembangan karakter secara mikro dalam konteks dikelas khususnya kelas X TB 2.

Implementasi nilai-nilai multikultural terhadap respon siswa yang tertuang dalam 9 indikator nilai-nilai multikultural yaitu kedamaian, keterbukaan, menerima keindahan perbedaan, penghargaan timbal balik, pemahaman timbal balik, cinta dan kasih sayang, perhatian, menghargai kebaikan orang lain, menghargai situasi-situasi orang lain dengan cara menampung respon para siswa melalui hasil angket dan kuisioner keseluruhan para informan menyatakan sangat setuju dalam mengimplementasikan indikator kedalam kehidupan para siswa.

Dari berbagai program berkarakter tersebut, SMK PGRI 1 Badung mendapatkan pembinaan dan pembiasaan dalam menumbuhkan sikap bertoleransi antar umat beragama hal tersebut pembiasaan untuk menghormati bila ada para siswa yang sedang melaksanakan kegiatan ibadah nya. Dalam implementasi nya juga diawali dengan perencanaan yang meliputi visi misi sekolah, pembelajaran dalam sekolah, mengupayakan terciptanya lingkungan pendidikan yang bebas dalam beribadah dan tidak ada nya pembatasan apapun, sekaligus meliputi sarana penanaman toleransi sebagai solusi dari isu perpecahan, dan upaya pendidikan multikultural dalam kehidupan beragama dilingkungan sekolah. Adapun dua komponen sekolah yang berperan strategis dalam mengimplementasikan nilai-nilai multikultural di SMK PGRI 1 Badung yaitu Kepala Sekolah dan Guru dalam setiap mata pelajaran.

Nilai-nilai yang peneliti ajukan berupa saran dan masukan untuk pihak-pihak berkepentingan terhadap hasil penelitian ini. Penulis berharap agar ini menjadi manfaat untuk perbaikan dan memperjelas tentang nilai-nilai multikultural. Adapun beberapa hal dari saran yang diajukan oleh peneliti sebagai berikut :

1. Bagi siswa, hendaknya selalu menjaga kerukunan dan terus melatih diri untuk selalu bertoleransi dan menghormati setiap perbedaan yang ditemui dalam kehidupan sehari-hari khususnya saat berada di lingkungan sekolah agar tidak ada konflik atau perpecahan.

2. Bagi sekolah, hendaknya terus melakukan pengembangan dan perbaikan serta inovasi dalam menerjemahkan program-program yang sesuai dengan nilainilai multikultural khususnya untuk menanamkan nilai-nilai toleransi peserta didik. Jadikan hasil laporan ini sebagai bentuk evaluasi yang membawa program sekolah menjadi lebih baik lagi. Selenggarakanlah pendidikan karakter yang mampu dilaksanakan secara operasional oleh guru maupun oleh setiap pembimbing pada ekstrakurikuler.

3. Bagi masyarakat, hendaknya terus memberikan dukungan kepada sekolah dan pemerintah dalam mengimplementasikan nilai-nilai multikultural agar setiap tujuan yang hendak dicapai dalam pelaksanaan kebijakan ini dapat tercapai secara optimal. Adanya laporan ini harus menjadi dasar bagaimana peran masyarakat dalam berpartisipasi menyukseskan nilai-nilai multikultural.

4. Bagi peneliti selanjutnya, penelitian ini dirasa masih belum memuaskan dan masih banyak hal-hal yang harus dikaji, sehingga peneliti selanjutnya diharapkan mampu melakukan pengembangan yang bukan hanya pada nilai-nilai 
multikultural saja, melainkan juga mengkaji dampak pembinaan toleransi di sekolah terhadap kondisi masyarakat sekitar sekolah.

\section{DAFTAR RUJUKAN}

Abdullah, Ridwan. 2015. Pembelajaran Saintifik Untuk Implementasi Kurikulum 2013. Jakarta : Bumi Aksara.

Adisusilo, Sutarjo. 2017. Pembelajaran Nilai Karakter. Jakarta : Raja Grafindo Persada.

Alwasilah. 2015. Pokoknya Kualitatif : Dasar-dasar Merancang dan Melakukan Penelitian Kualitatif. Bandung : Kiblat Pustaka Jaya.

Ekha Budi Santosa, dkk. 2016. Implementasi Dalam Pendidikan Karakter di SMA Kristen Pelita Nusantara Kasih Surakarta. Surakarta. Jurnal : Penerbit Universitas Sebelas Maret.

Gunawan, Ary. H. 2010 . Sosiologi Pendidikan : Suatu Analisa Sosisologi Tentang Pelbagai Problem Pendidikan.Jakarta. Rineka Cipta.

Hidayatullah Al Arifin, Akhmad. Implementasi Pendidikan Multikultural:Dalam Praksis Pendidikan Di Indonesia, Jurnal Pembangunan

Pendidikan: Fondasi dan Aplikasi, Volume 1, Nomor 1, Juni, 2012,

Kementrian Pendidikan Nasional. 2013. Pengembangan Pendidikan Budaya dan Karakter Bangsa. Jakarta : Pedoman Sekolah.

Mu'min, Ma;mun. 2012 . Pendidikan Multikultural Dalam Perspektif Filosofis. Kudus. Jurnal STAIN Kudus.

M. Arifin, dkk. 2016. Instrumen Penelitian. Malang. Jurnal. Penerbit : Universitas Negeri Malang.

Ridwan, Abdullah. 2015 . Pembelajaran Saintifik Untuk Implementasi Kurikulum 2013. Jakarta ; Bumi Aksara.

Ratih, Komang Kumara. 2017. Pengaruh Penerapan Metode Inkuiri Terhadap Hasil Belajar IPS Siswa Kelas V SDN 1 Binakarya Buana Lampung. Lampung. Tesis. Penerbit : Universitas Negeri Lampung.

Sujarweni, Wiratna. 2015 . Metodologi Penelitian Bisnis dan Ekonomi. Yogyakarta. Pustaka Press Baru.

Suryadi, K. 2011 . Kompetensi Sosial Masyarakat Majemuk. Bandung ; Widya Aksara Press.

Sutiah 2010 . Pendidikan Agama Islam. Malang. NLC.

Thaufan Abiyuna, R. 2017 . Implementasi Pendidikan Berkarakter Dalam Menumbuhkan Sikap Toleransi Antar Umat Beragama

Siswa. Bandung. UPI Skripsi.

Wiratama, Adi. 2010 . Pluralisme Agama Menurut Nurcholish Madjid.

Surakarta. Thesis 2010.

Zaini 2010 . Penguatan Pendidikan Toleransi Sejak Usia Dini. Bogor. 